\title{
Ossianic gold: an enhanced object biography of a Viking Age or Late Norse finger-ring from the Isle of Jura in the collection of Glasgow Museums
}

\author{
Katinka Dalglish ${ }^{1}$ \\ with James Graham-Campbell ${ }^{2}$
}

\begin{abstract}
A Viking Age or Late Norse gold finger-ring in Glasgow Museums (A.1979.19), previously thought to have been found in the Isle of Skye, is here identified with a ring said to have been found in the Isle of Jura in 1869 (together with another, now lost). This identification is based on an illustration published in 1875 by the ring's then owner, the Rev Dr P H Waddell (1816-91). Waddell's use of the ring as a piece of evidence in his attempts to prove the authenticity of James Macpherson's Ossianic poems is discussed. The ring subsequently passed into the possession of the Austrian Countess Vincent Baillet de Latour (d 1942), who had developed an interest in the archaeology of Skye during her first marriage to Norman Macleod of Macleod (d 1895). Focusing on the ring as a collector's possession, the paper takes a biographical approach, following its trajectory from antiquarian discovery to museum object.
\end{abstract}

\section{INTRODUCTION}

In 1979 Glasgow Museums acquired a gold finger-ring at the Christie's Fine Antiquities sale held in London in November of that year (Illus 1). The ring was described in the auction catalogue as follows:

A FINE CELTIC BRONZE AGE GOLD EARRING comprising a penannular loop of twisted tapering form - lin. (2cm) diam., Early First Millennium B.C.

Provenance: The Isle of Skye ... the ring was gifted by the wife of one of the MacLeod chiefs, an Austrian lady, the Countess Latour (or de la Tour) ... as a mark of esteem ... about the year 1916.

The material of which this earring is made is almost certainly Irish gold. Similar objects have been found over a wide area of Ireland, Wales, southern England and north-east France in association with gold bar torques. It has been transformed into a finger ring in recent times (Christie's 1979: 12, lot 28).

The acquisition prompted Dr D W Phillipson, then Keeper of Archaeology, Ethnography and History at Kelvingrove Art Gallery and Museum, to make enquiry of the vendor (through Christie's) into the object's provenance. The response (dated 2 January 1980) contained no information at all concerning the ring's discovery (or find-site), but only the fact that it had 'originally belonged to the Countess Latour' who had presented it to her farm-manager in the Isle of Skye 'on his retiral in 1931'. The Countess Latour's then retiring manager was the great-uncle of the vendor's cousin, and so it is assumed that the ring subsequently passed down to him or her through familial descent. The significance of the year 1916, forming part of the ring's provenance as given in the auction catalogue, in the form of an abbreviated

1 Kelvingrove Art Gallery and Museum, Argyle Street, Glasgow G3 8AG

Email: katinka.dalglish@glasgowlife.org.uk

${ }^{2}$ UCL Institute of Archaeology, 31-4 Gordon Square, London WC1H 0PY

Email: j.graham-campbell@ucl.ac.uk 


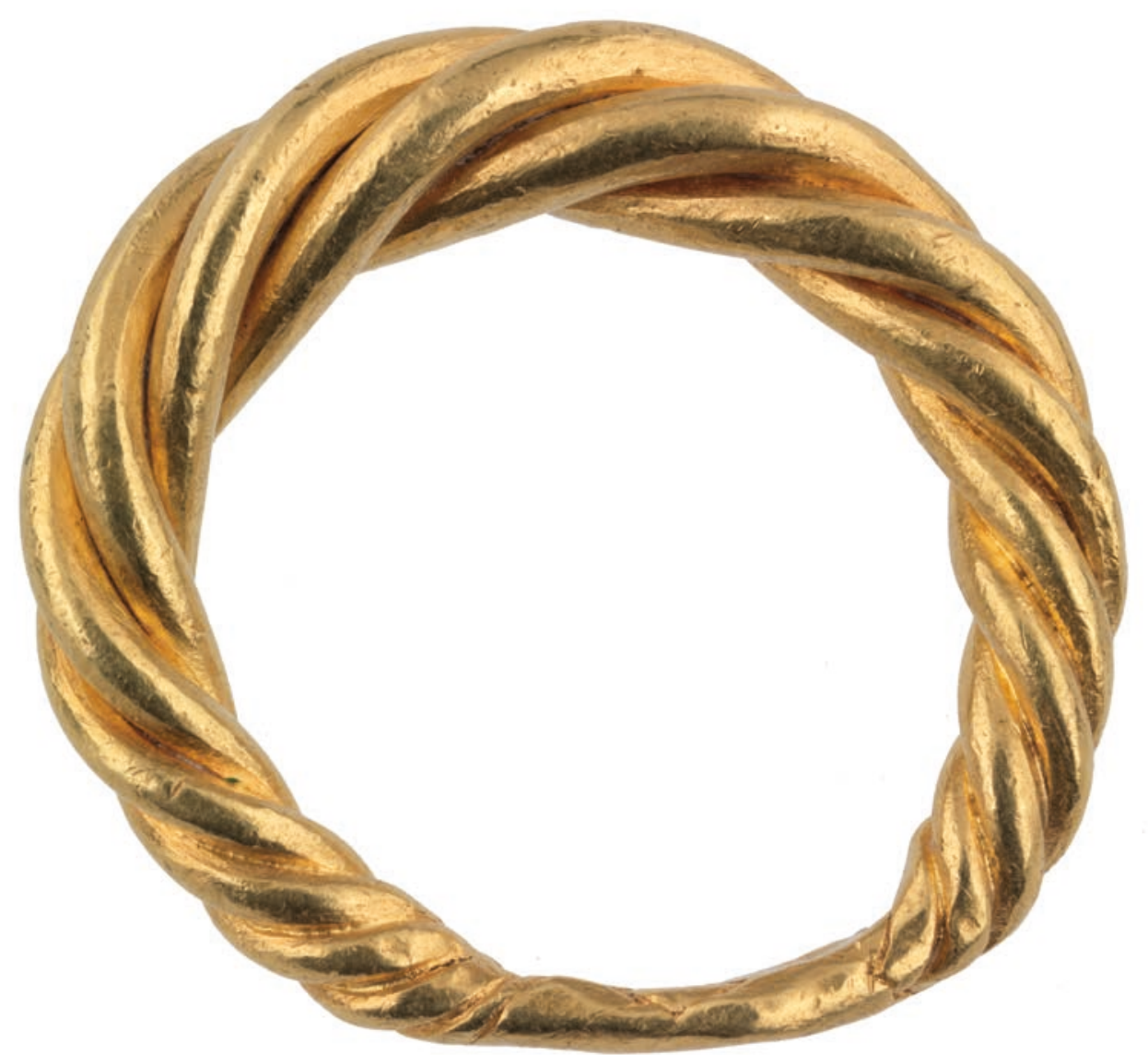

ILLus 1 The Viking Age or Late Norse gold finger-ring in Glasgow Museums' collection, accession no. A.1979.19. (C) CSG CIC Glasgow Museums Collection

quotation (see above), remains unclear - if not an actual error.

Evidently not a modified Bronze Age earring of the early 1 st millennium $\mathrm{BC}$, as claimed in the auction catalogue, the ring was examined by James Graham-Campbell and published in this journal in 1982, and again in his 1995 monograph The Viking-Age Gold and Silver of Scotland. These publications established the ring as a Viking Age or Late Norse finger-ring of Scandinavian type, with a 10th- to 12th-century $\mathrm{AD}$ date-bracket, and 'said to have been found before 1916 on the Isle of Skye' (Graham-Campbell 1982: 568; 1995: 159, no. S13, pl 73,f). This latter statement regarding the date of the ring's discovery was based on a misunderstanding of the information given in the auction catalogue. Until recently, these details, along with technical data on the ring's size and production and its relationship to available comparanda, represented the total sum of knowledge about it.

Arguably, this makes for a limited object biography. While this situation might be addressed by considering more closely each stage of the object's life-cycle, such as its manufacture or use, its complete lack of archaeological context inevitably circumscribes the scope of such an analysis. Instead, this paper focuses on examining the object's journey from private possession to museum object in order to enhance the story of its post-discovery life. For the vast majority of that time thus far, the object has been 
in private circulation, which means that much of its biography is to be derived from the uses it was put to and the purposes it served while it was a collector's possession. The merit, in this case, of taking a biographical approach lies in its ability to reveal relationships between the ring and its owners, and to define some of the changing identities conferred upon the object along the way.

New information concerning the fingerring's discovery has called into question both its alleged 'Isle of Skye' provenance and its supposed date of discovery, in consequence of its identification with a gold ring illustrated in a 19th-century antiquarian publication. As a result, the authors propose below that this supposed 'Isle of Skye (pre-1916)' single find be deleted from the corpus and replaced with an 'Isle of Jura (1869)' hoard.

The 1979 acquisition of the ring and its subsequent publication in 1982 (GrahamCampbell 1982) may be considered the point at which it was removed from private circulation and entered public and scholarly awareness. Simultaneously, this also marked a crucial point in the cementing of the ring's anecdotal 'Isle of Skye' provenance, as this became written into institutional object documentation and scholarly literature for the first time. The attribution of the ring to an unknown find spot in the Isle of Skye may have rested on the testimony of the vendor and, at the time, provided a reasonable and plausible account for the object's provenance.

However, new research by Katinka Dalglish has led to a reconsideration of the ring's provenance. The key piece of evidence for this is the volume Ossian and the Clyde, Fingal in Ireland, Oscar in Iceland or Ossian Historical and Authentic written by the Rev Dr Peter Hately Waddell (1816-91) and published in Glasgow in 1875. This book includes an illustration of a twisted rod finger-ring (Illus 2), the form and characteristics of which are sufficiently similar to the 'Isle of Skye' ring in Glasgow Museums' collection to have warranted this further investigation. Indeed, we offer the conclusion that the finger-ring depicted by Waddell, which was owned by him and stated to be one of two discovered together in the Isle Jura in 1869, is the

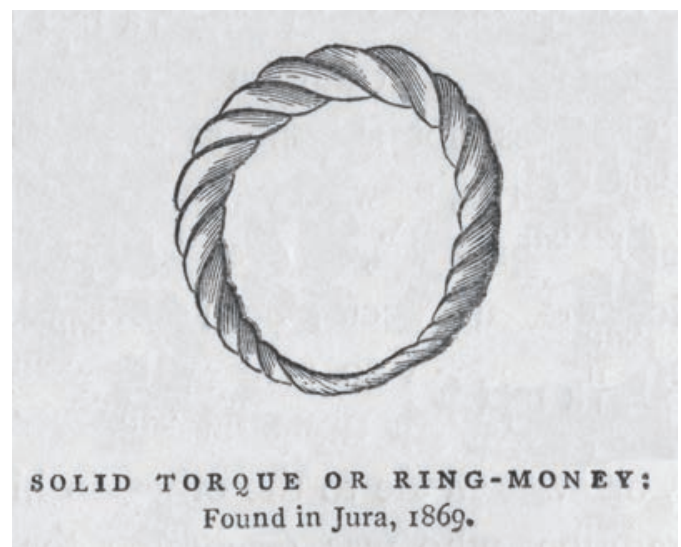

ILLus 2 Engraving of the gold ring 'found in Jura' in Waddell's possession, from Ossian and the Clyde (Waddell 1875: 310)

same ring as that subsequently in the possession of Countess Latour (until 1931).

The ring, which was accessioned into Glasgow Museums' collection under the registration number A.1979.19, is an annular finger-ring composed of four gold rods twisted together, tapering towards the ends and linked by a plain, lozenge-shaped plate (Graham-Campbell 1982; 1995). The ring has a noticeable distortion to its hoop causing it to have a distinctive subcircular shape, varying in diameter between $25 \mathrm{~mm}$ and $27 \mathrm{~mm}$. The rods are twisted in what may be described as an S-twist. Comparison with the illustration in Waddell's book shows a twisted rod finger-ring of the same size, with a similar distortion to its hoop and identical execution of the linking plate. However, this illustration depicts the ring as having a Z-twist, that is with the rods twisted in the opposite direction to Glasgow Museums' ring, but given that the illustration was produced from an engraving, it is most probable that it is in fact a mirror image of the original drawing. Flipping the printed image turns the depicted Z-twist into an S-twist, revealing how closely it matches Glasgow Museums' finger-ring, not only in the direction of the twist, but also in the graduation of the thickness of the gold rods to the plain linking plate, with the same distinctive distortion of the hoop (Illus 3). Although the engraving 


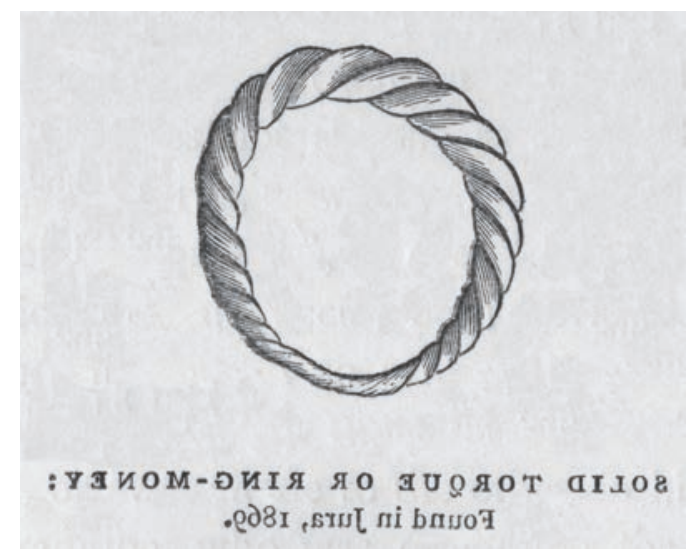

does not accurately delineate the four-rod twist of the extant ring, the exact nature of the ring's manufacture is only apparent from detailed study and so there need be no surprise that the engraver represented it as a more conventional threerod twist. The fact is that there is no evidence with which to verify, or even substantiate, the saleroom provenance of the Countess Latour's finger-ring (see further below) and if it is not to be equated with Waddell's ring, then the latter is lost because there are no unprovenanced twistedrod finger-rings with which it might alternatively be identified in any British public collection (cf Graham-Campbell 1995; 2011). On balance, however, there is an extremely strong case for identifying the finger-ring in Glasgow Museums' collection with that illustrated in Waddell's book, and so for questioning inherited knowledge about its provenance.

Accepting this proposition opens up the possibility of adding considerable depth and detail to the object's biography. By filling in some of the gaps in our knowledge about the ring's history we may begin to discern a story somewhat more complex and richer in detail, and one which exemplifies the concept that collected objects can, and often do, have multiple changing identities over time. It will become apparent that the ring, while in Waddell's ownership, served a specific purpose as a piece of evidence in an elaborate antiquarian arrangement aimed at proving the legitimacy and historicity of James Macpherson's Ossianic poems.

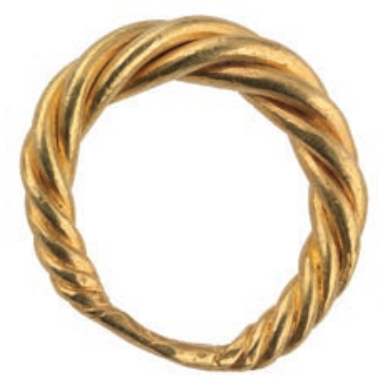

ILLus 3 Waddell's (1875) illustration of his gold fingerring from Jura (flipped), compared with that in Glasgow Museums (after Illus 1 and 2)

\section{THE REV DR P H WADDELL}

The Rev Dr Waddell was an independent evangelical minister in Girvan and, then, in Glasgow from 1862. His monograph Ossian and the Clyde (1875) was the culmination of years of meticulous, almost obsessive, study of James Macpherson's Ossianic poems and the world in which the sublime tales unfolded and the poems' dramatis personae lived. This was a universe in which Waddell perceived immense beauty, grandeur and profound melancholy, unrivalled heroism and true human greatness. Crucially, it was also an ancient world which had long ceased to exist except in the poetic legacy of Ossian. Waddell's contribution to the enduring Ossianic controversy came through his attempt to authenticate the poems as legitimate, ancient compositions and to vindicate their translator, Macpherson. Waddell held that Ossian was an authentic bard, his poems were genuine, and Macpherson merely an interpreter, not a fabricator. The resulting 426-page monograph is a testament to his unyielding commitment to his own very particular reading of Ossian, or as Eric Gidal put it: 'a compendium of ethnogeomorphological speculation' (Gidal 2015: 156).

The premise of the book is the proposition that the setting of the Ossianic narrative, as described in the poems, was identifiable and verifiable in the geography, geology, geomorphology and archaeology of Scotland, Ireland and Iceland, sometimes in minute detail. Waddell confidently, 
but speculatively, unravelled and transposed most of the poems' scenery to localities in Galloway, the Isle of Arran, the Clyde Valley, Cowal and the Argyllshire coast, Stirlingshire, Ulster and Iceland. However, as Ossian was ascribed to a time when sea levels, Waddell theorised, were some 60-70ft (18-21m) higher than their Victorian levels, some seaborne routes of communication had been possible that were no longer. Postulating the existence and navigability of such routes allowed Waddell to rationalise what might otherwise seem like geographical inconsistencies in Macpherson's texts. However, as these chronologically remote Ossianic landscapes had changed so considerably by Macpherson's lifetime, he could not possibly have been familiar with their former appearance, therefore he could not have described them accurately and consequently he could not have authored the poems. This was conclusive proof, Waddell held, of the poems' antiquity and evidence that they were not 18th-century forgeries being passed off by Macpherson as faithful translations of ancient originals.

Eric Gidal has dexterously peeled back the multiple layers of Ossian and the Clyde, particularly in terms of its significance as a contribution to the environmental historiography of Glasgow and the Firth of Clyde, even if this was incidental to Waddell's chief objective of authentication. In his quest to situate Ossian within the deep history of the region Waddell simultaneously documented the longterm geomorphological transformations of a once radically different landscape and the contemporary, relentless and often degrading transformations caused by an ever expanding, industrial, networked city (Gidal 2015). By contrast, Macpherson's Ossian embodied a vastly superior ancient past in which magnificent landscapes, unspoilt and unobscured by 19thcentury factory smoke, sewage and emissions, were inhabited by a noble people of the highest moral qualities. Macpherson's 18th-century and Waddell's 19th-century worlds felt far removed from this ancient idyll:

[T] he morality of our largest Christian communities has become a scandal to Christ; and [...] the revelations of the race-course, the Divorce Court, and the Stock Exchange [...] seem to be actually annihilating Christianity (Waddell 1875: 41).

Waddell felt that the communities had become ethically and spiritually degraded: slavery and commercial exploitation were the order of the day; industrial progress had scarred a once picturesque and familiar landscape; and 'revelations of indecency in domestic life, from the palace to the pavilion, [...] shocked the very heavens'. Yet these morally degraded communities saw themselves fit to pass judgement on Ossian and Macpherson, rejecting the poems as brazen forgeries and their avowed translator as a cunning plagiarist, a cheat and a ruffian (Gaelic Society of Inverness 1878: 65, 86).

Though not the only contribution to Ossianic geography, Waddell's approach was, and remains, unique. Insisting on their authenticity, he postulated that the poems contained reliable detail about the physical world inhabited by Ossian and his people. Significantly, he held that the poems represented a neglected source of antiquarian intelligence, unrecognised or wilfully dismissed by unbelievers. Effectively a chronicle of the Ancient Caledonians in the 3rd century AD, hidden in plain sight, this aspect of Ossian's poems had been misunderstood and ignored by generations of critics. Underwritten by Waddell's unshakable belief that Ossian was a font of valid historical data, Ossian and the Clyde was his attempt to set the record straight.

Biographical accounts of Waddell often comment on his striking appearance, his peculiar tone of voice and, especially, his exceptional talent as an orator (John O'Groats Journal, 18 December 1862: 2; Dundee Evening Telegraph, 5 May 1891: 2; Lawson 1892) (Illus 6). Eloquence, fervour, honesty and fearlessness are terms that appear again and again: 'The heart and soul of the man flash out in every word he utters', commented the Stirling Observer in 1861 (28 November 1861: 2). John Stuart Blackie, Professor of Greek at the University of Edinburgh, untiring campaigner for the establishment of a Chair of Celtic and defender of the land rights of Highland crofters, declared that Waddell was the most eloquent preacher in all of 
Scotland (The Scotsman, 25 December 1897: 9). A brief biographical note by his son, also Peter Hately Waddell (1854-1922), describes a lover of spiritual freedom, an opponent of dogma and doctrinal divisions whose religion crossed over into all aspects of life, encompassed and touched upon everything that he felt was true and right (Waddell 1892), including the defence of Ossian and Macpherson.

The fundamental historicity of Ossian was unquestionable; his belief in it was instinctual and intuitive, like his faith in the authenticity of the Gospels. The Sermon on the Mount and the Lord's Prayer

go utterly beyond our poor modern patchwork existence, and, like all true words of God, take the universe in. On the same principle, although the subject matter be entirely different, I would rely on the authenticity of Ossian (Waddell 1875: 32).

Waddell's conflation of religious faith with Ossian situates him among a group of contemporary church ministers, among whom were several Highlanders and respected Gaelic scholars, who cultivated belief in the poems as if they had been biblical texts. This included the Rev Robert Blair, minister to the Gaelic-speaking congregation at St Columba's in Glasgow, of whom Waddell thought very highly, as well as the Rev Archibald Clerk of Kilmallie, Argyll (Meek 2004: 52). Indeed, it was a lengthy and predominantly complimentary review by the Glasgow Herald (9 March 1871) of Clerk's 1870 retranslation of Ossian which prompted Waddell to write a series of letters to the newspaper regarding the authenticity of Ossian. These letters formed the foundation of Ossian and the Clyde and set out Waddell's position in no uncertain terms.

When Ossian and the Clyde came out in 1875 , Waddell sent a copy to pioneering folklorist and polymath John Francis Campbell, anxious for Campbell's opinion on his book. Campbell was known for being intensely unsympathetic towards Ossian and the marginalia in his copy of Waddell's book, now in the J F Campbell Collection in the National Library of Scotland, reveal him as a harsh critic: 'June 23 rd Tried hard to read so as to understand the drift and could trace no sign of proof, or of anything beyond faith. An excellent quality but here pinned to a grand fiction', and later: 'This is the most hopeless man that I ever fell in with [...]. In short his name suggests Hateful Twaddle' (Waddell 1875, National Library of Scotland Shelf Mark Cam.1.b.17). Campbell's collaborator, Islay schoolmaster Hector Maclean, also reviewed the book and was barely more lenient. Over the course of a caustic exchange in the pages of the Coleraine Chronicle, Maclean, who ostensibly had the scholarly upper hand, effectively demolished Waddell's work in 1876:

To attempt to torture geology out of Macpherson's writings, or accurate history out of traditions, myths, fables, giants, and giantesses, in this enlightened age, is supremely ridiculous. So much, however, is Dr Waddell in love with his Ossianic phantasms that no amount of evidence, as it appears to me, can convince him of their absurdity and baselessness (Maclean 1876).

If faith, then, was the foundation in which Waddell's relationship with Ossian was anchored, the question of authenticity transcended the need for evidence. Although almost everything Waddell wrote on the subject was peppered with references to archaeological discoveries and conjectures on geology, geomorphology, toponomy and etymology, he maintained that such hard, irrefutable arguments were 'entirely supplementary for the benefit of others' and by no means superior to the argument of instinct. He wrote:

Nor was it the building or finding of canoes at random - here, there, or anywhere - on which I relied; but their proved construction exactly as Ossian describes it; and their recent discovery on the very spot on which, according to Ossian, they should be found (Glasgow Herald, 6 April 1871: 7; Waddell 1875: 39).

Nevertheless, it is evident that archaeological monuments and artefacts served as material nodes with an Ossianic past and often with specific poetic characters. The ancient monuments of Arran had a particular draw on Waddell, as Arran was where he located some of the key events of the poems' narratives: the 
deaths and interments of Ossian, the blind bard; of Malvina, his adopted daughter and wouldbe daughter-in-law; of Oscar, his son; and of Fingal, his father. An initial reconnaissance carried out in July 1871, while holidaying on the island, led Waddell towards two burial mounds, one at Margreeach Farm near Glenree, and one at Torlin (Torlin chambered cairn, NMRS no. NR 92 SE 2). The former, Waddell stated, had been 'bored long ago by some daring islander', while the latter had been rifled through by 'a modern Goth', quoting here from John MacArthur's The Antiquities of Arran (1862: 23). The 'modern Goth' was probably the Torlin farmer, said to have strewn the bones over his fields and taken a skull home, before suffering a violent death a few months later for his irreverence. Waddell dismissed the two mounds as evidently being collective burials for several people, and therefore unlikely, in his opinion, to fit the bill as the burial of an individual, illustrious chief. Nearby Clachaig ('Ossian's Mound', Clachaig, NMRS no. NR 92 SE 1), however, was more promising and traditionally held to be the spot where Ossian had died. Thus on Waddell's second trip to Arran, in July 1872, attended by his own family, the tenant farmer $\mathrm{Mr}$ Speirs, the local minister and numerous other people, he dug into the mound, but found only an empty cist. In fact, Speirs had already dug into the mound several years before as had his father before him, although the latter had been deterred by onlookers praying to avert his instant death - the penalty for his impending sacrilege. Nonetheless, Waddell was satisfied that this was indeed the final resting place of Ossian. He identified a now robbed-out cairn at Blackwaterfoot as Malvina's grave (NMRS no. NR 82 NE 2), a different cairn at Margreeach Farm as Oscar's grave (most likely NMRS no. NR 92 SW 3), and two particular (probably natural) granite blocks, among a mile of similar granite blocks strewn across the heather-clad hillside between Corriecraivie and Kilpatrick on Arran's west coast, as Fingal's grave. A ground plan and several sketches of the sites reproduced in Ossian and the Clyde were intended to lend added authority to his identifications (Waddell 1875: 50-95).
Discoveries of logboats served the dual purpose of proving Waddell's theory about the higher sea levels which had made the Clyde a navigable fjord as far as Rutherglen, and proving that the ancients had boats just like those described by Ossian. He makes reference to at least seven separate discoveries of logboats, including the 1726 discovery of a logboat in the River Carron (NMRS no. NS 88 SE 88); those from Kilbirnie Loch, North Ayrshire (NMRS no. NS 35 SW 5), and Bowling on the Clyde (NMRS no. NS 47 SW 12), all discovered in 1868; the 1874 discovery of a logboat in Loch Arthur, Dumfries and Galloway (NMRS no. NX 96 NW 3); a pre1848 discovery in Drygate, Glasgow (NMRS no. NS 66 NW 16); an undated discovery near the Saltmarket, Glasgow (possibly NMRS no. NS 56 SE 37); and one found in the River Forth at Cambuskenneth in 1874 (NMRS no. NS 89 SW 28) (Mowat 1996). Here were Ossian's 'dark riders of the wave' (Waddell 1875: 33), which had carried Fingal and his men on their long and dangerous voyages. The inland location of the Drygate logboat further suggested to Waddell that the nearby Molendinar burn had been a significant branch of the Firth of Clyde at the time the boat was deposited. Similarly, an axehammerhead in Glasgow Museums' collection (accession no. 1875.7.a), discovered beneath $4 \mathrm{ft}$ (1.2m) of sand near Stobcross House (NMRS no. NS 56 NE 42), proved to Waddell that Stobcross had been under water at the time, and that 'the curious relique in question' had been dropped from a logboat travelling up the Clyde, then a fjord (Glasgow Herald, 9 March 1875: 7).

Several hundred raths and mounds enumerated by antiquarians in Co Antrim, and the 'arrow heads and curious Danish trumpets, and brass and bronze implements of war' found within them, were the burial mounds and personal belongings of slain warriors buried among the dwellings of the victorious, precisely as described in the Ossianic poem of 'Temora' (Waddell 1875: 120). Throughout, Waddell's wide reading of Ossian attempted to validate passage after passage by decoding allusions to structures and objects and identifying these with real-life ancient monuments and artefacts. Often, this resulted in faulty arguments that legitimised 
both the poems as sources of genuine Ossianic, historical data, and the Ossianic date of the archaeology that legitimised the poems in the first place.

Even after the publication in 1875 of Ossian and the Clyde Waddell continued to pursue archaeological proof. In October 1876, the discovery of a complete Roman Samian ware bowl at Fleshers' Haugh by Glasgow Green (NMRS no. NS $66 \mathrm{SW} 1$ ) prompted another letter by Waddell to the Glasgow Herald. He argued that as the bowl, now in Glasgow Museums' collection (accession no. 1877.1) (Illus 4), had been found some $4 \mathrm{ft}(c 1.2 \mathrm{~m})$ below ground it must have been dropped into deep water from a boat, like the Stobcross axe-hammerhead about which he had written to the paper the previous year (Glasgow Herald, 9 March 1875: 7; Glasgow Herald, 20 October 1876: 7). These finds fitted neatly into his assumptions about the former levels of the Clyde, on which his Ossianic geography relied.

In September 1878 another opportunity to investigate ancient burials in Ossianic territory presented itself, this time on the island of Great Cumbrae in the company of Dr John MacGown, Millport's doctor, Mr Charles Adolphe Chardenal, a retired French teacher, and Mr Edward Alfred Wünsch, a Bavarian-born businessman and VicePresident of the Glasgow Geological Society (MacGown 1883: 116; Macnair \& Mort 1908: 31). Waddell knew Chardenal from serving on the Committee of the High School of Glasgow, where Chardenal had taught French in the early 1870 s. It is likely that he was also already familiar with Wünsch who had gained some renown in the field of geology for his 1865 discovery in the Isle of Arran of stems of fossil trees embedded

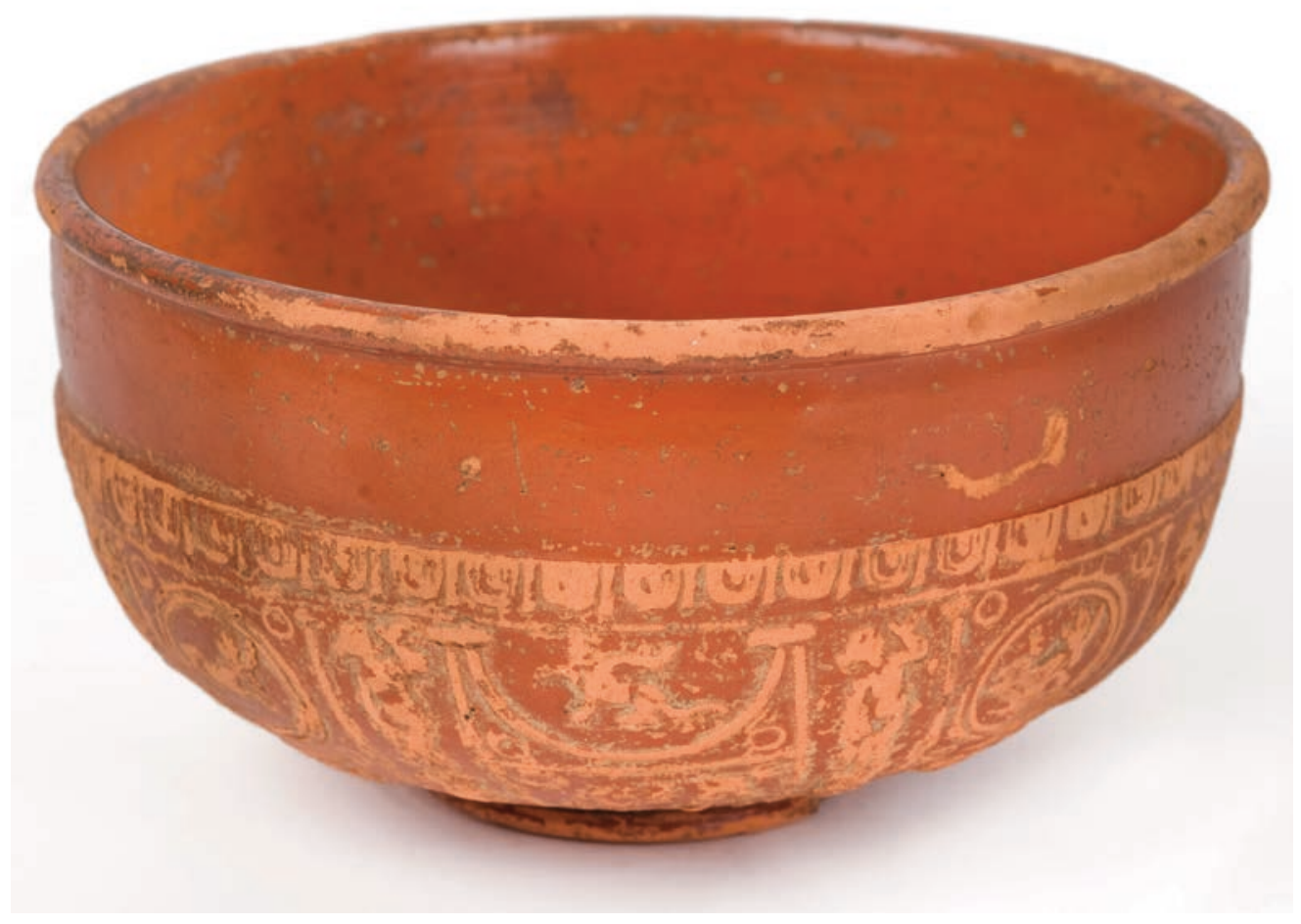

ILLus 4 Samian ware bowl found about 1.2m below ground at Glasgow Green, in 1876, and supposed by Waddell to have been dropped into deep water from an Ossianic logboat (Glasgow Museums' collection, accession no. 1877.1). (C) CSG CIC Glasgow Museums Collection 


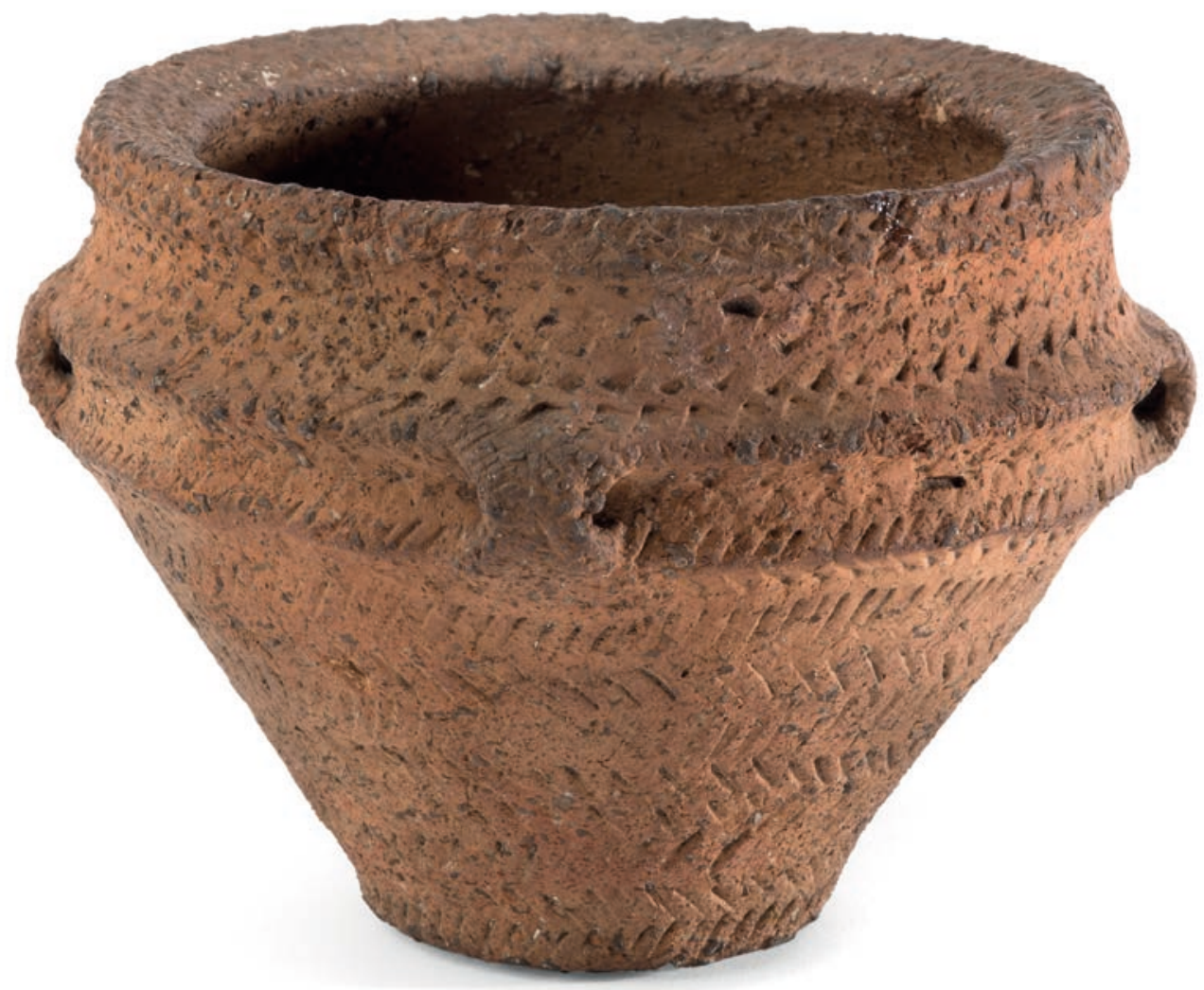

Illus 5 Urn excavated by Waddell, MacGown, Chardenal and Wünsch from a cist at Tomont End, Great Cumbrae, in 1878 (Glasgow Museums' collection, accession no. 1878.177.b). (C) CSG CIC Glasgow Museums Collection

in layers of ash (Wünsch 1865: 474; Lyell 1871: 530). The gentlemen's excavation at 'Lady's Grave', Tomont End (NMRS no. NS 15 NE 2), yielded a cist containing an urn with cremated bones resting on a base of white pebbles. The urn, a beautifully decorated Food Vessel with four lugs, is in Glasgow Museums' collection (accession no. 1878.177.b) (Illus 5). It was displayed in the 'Scottish Archaeology' section inside James Sellar's fantastical plasterboard reproduction of the Bishop's Castle during the 1888 International Exhibition in Kelvingrove Park (Paton 1890: 11). Inside the Bishop's Castle one room was decorated with an extract from Waddell's highly rated translation of the 23rd Psalm into Scots, running in a band around the walls (Glasgow Herald, 25 May 1888: 9).
A chapter of Ossian and the Clyde was devoted to a taxonomy of the ancient Caledonians (allegedly the people of Fingal and Ossian) organised under headers such as 'Geography', 'Warlike Equipments and Usages', 'Habits, Customs, Arts', 'Dress and Morals' and 'Superstitions' (Waddell 1875: 293-8). Arguably a standard Victorian approach to understanding societies and their material culture, in Waddell's case the exercise served to authenticate the poetic characters by providing his readers with a range of credible 'facts' and statistics about them. He held that, among the ancient Caledonians, 'graceful ornaments for the head, neck, and wrists, called torques', made of the purest gold, were supposed to have been worn exclusively by chiefs and men of distinction. He was aware 
that several discoveries of such ornaments had been made in Arran and the north of Ireland, the very regions where Fingal and his men had roamed. Ossian's relative silence on the subject of gold was taken by Waddell to mean that gold had been exceedingly rare and precious, and consequently not commonly available or worn except in special circumstances. Arguing that the ancient Caledonians had obtained gold from the 'land of the strangers', probably Romanised Britons living south of the Clyde, who in turn had acquired it from Phoenician traders (Waddell 1875: 305), lent an added sense of exquisiteness and allure to the imagery. In fact, Waddell had in his own collection a small, annular, gold ornament,

supposed by antiquarian authorities to have been used as money; and to have been carried either slung on thongs round the neck, or attached to the dress as ornaments, in the same way as Highlanders are said to still wear silver buttons on their coats to defray charges in a foreign land for sick-bed or funeral (Waddell 1875: 305).

A gilt-stamped engraving of this ring adorns the front cover of Ossian and the Clyde. The same engraving appears on an otherwise blank flyleaf preceding the half-title, and again towards the end of the book (Illus 2), where it is accompanied by a caption identifying it as a 'Solid torque or ring-money: Found in Jura, 1869' (Waddell 1875: 310$)$. Its prominent position on the book's front cover suggests that the ring was of great significance to Waddell. Indeed, Waddell is wearing the ring above his signet ring on his left hand in John Henry Lorimer's dramatic portrait of him (Illus 6), presented to Glasgow Museums in 1903 by Waddell's eldest son, James (accession no. 1063). As a 'solid torque', the ring fulfilled the role of eye-catching accessory in a complicated antiquarian fantasy, enhanced by Jura's central location within an imagined Ossianic seascape. As Waddell's personal belonging, the ring provided him with a palpable connection to Ossian's Fingalian warriors and an idealised, ancient and lost Scotland.

Little is known about Waddell's personal collection except that he owned the gold fingerring from the Isle of Jura acquired $c$ 1869-74, two miniature portraits of Robert Burns and his son, acquired in 1866 (Waddell 1867, Vol 2: appendix, lxvii), and a collection of historic maps acquired around 1865 (Glasgow Herald, 4 June 1868: 4). According to Waddell, the gold ring was one of two discovered together in the Isle of Jura in 1869 (1875: 305). As he appears to have finalised his manuscript for Ossian and the Clyde around the autumn of 1874 , he must have acquired the ring between 1869 and 1874 . He gives no further clues as to the find spot or the identity of either the finder or the seller, and Ossian and the Clyde is the only source known at present to document this particular discovery. This is the ring which the authors of the present paper suggest is to be identified with the Norse gold finger-ring in Glasgow Museums' collection (A.1979.19), based on their close physical resemblance.

The opinions of critics were divided as to the authenticity of Waddell's unsigned miniature of Burns, not least owing to its remarkable dissimilarity to his well-known likeness by Nasmyth. Waddell, however, was indifferent; his miniature treasure spoke to him and captured the poetic genius of Burns whom Waddell venerated as he venerated Ossian and Homer. As with the Ossianic poems, Waddell's belief in the authenticity of his miniatures came down to instinct.

Waddell's historic maps included two late 16th-century maps of Africa which prompted him to launch into the ongoing debate about the source of the Nile. Waddell claimed that his own maps accurately depicted the true circumstances of African equatorial geography and hydrography and publicly pronounced himself to be the first person in Great Britain to illustrate and explain the matter 'by mere theoretical investigation' (Glasgow Herald, 16 December 1869: 7). He corresponded over several years with Dr David Livingstone to shed light on the subject and, there can be little doubt, in order to elicit endorsement of his own conjectures from a recognised expert in the field. In May 1868, convinced of the accuracy of his observations, Waddell wrote to Sir Roderick Murchison, President of the Royal Geographical Society, alerting him to the historic maps in his possession. Murchison appears to 


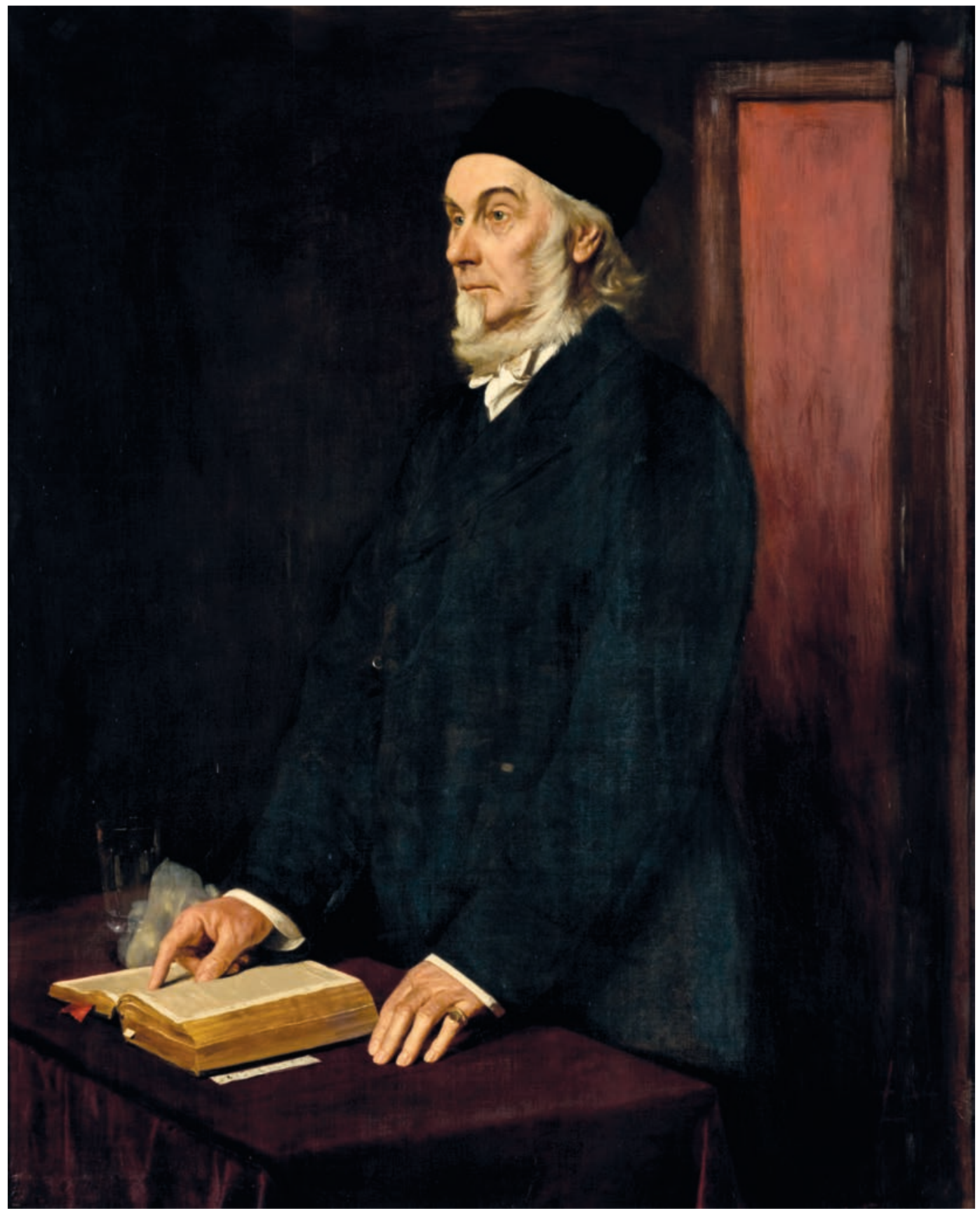

Illus 6 Portrait of P H Waddell by J H Lorimer (Glasgow Museums' collection, accession no. 1063). Note that Waddell is wearing his Ossianic gold finger-ring from Jura. (C) CSG CIC Glasgow Museums Collection 
have dismissed Waddell's maps as being of little value and ignored his subsequent letter. Waddell, who felt that his discoveries had not received the scholarly attention due to them, despite the fact that 'the very words employed by me have been almost literally confirmed by Dr Livingstone', insisted that, following the publication of his discoveries, he had received 'letters of congratulation from all parts of the kingdom, and from all sorts of persons except Royal geographers [...]' (Waddell 1868; Glasgow Herald, 4 June 1868: 4; 10 November 1869: 4; 16 December 1869: 7; Falkirk Herald and Linlithgow Journal, 16 April 1874: 3). Waddell's approach to this episode is closely paralleled by the way in which he went on to handle the rejection of his outpourings on Ossian less than two years later. Here we see Waddell claim to be the gatekeeper of hitherto unknown information of apparently enormous importance which was, however, being dismissed by the very experts who ought to have been able to recognise its authenticity. The confidence with which he argued for his theories on the hydrography of north-east Africa is entirely comparable to the conviction with which he defended his position on the hydrography of the Clyde Valley and the authenticity of Ossian. Just as he wrote to Livingstone and Murchison, possibly anticipating a rebuff from the latter, so he engaged with John Francis Campbell and Hector Maclean, undoubtedly aware that both would reject him wholesale. Thus it seems, Waddell's modus operandi was to tackle adversaries head on, armed with composure, eloquence and no small amount of faith.

In October 1890 Waddell retired from his ministry due to failing health and died in spring the following year at his home in Dowanhill in Glasgow (Dundee Evening Telegraph, 5 May 1891: 2; Lawson 1892: 28). Nothing is known of what happened to his collection, whether it was inherited by members of his family or sold. We are left to conjecture about the fate of the gold ring after Waddell's death and its subsequent acquisition by the Countess Latour (the widow of Norman Macleod of Macleod). It is plausible at least that the ring was sold by Waddell's family to a dealer and that information about its true provenance was lost in the process. In the following we shall explore the next chapter in the ring's biography during which it was owned by the Austrian-born countess and came to acquire an 'Isle of Skye' provenance.

\section{THE COUNTESS LATOUR}

Few details of the Countess Vincent Baillet de Latour's life are available to us, although her connection with Skye is well documented. As a young woman, by the name of Johanna ('Hanna') von Ettingshausen, the daughter of an Austrian baron, she married Norman Macleod of Macleod, the chief of the Clan Macleod, in the summer of 1881 at Graz, Austria.

Macleod was 42 years her senior and recently widowed. In 1849 he had been forced to give up parts of his hereditary lands in the Isle of Skye due to large debts, and the estate was taken over by the trustees of the family's creditors (Macleod 1906: 35; Devine 1994: 58). Macleod left his ancestral home at Dunvegan Castle and relocated to London with his first wife, Luisa, and their children, where he took a job to support his family. Initially, he worked as a junior clerk in the Prison Department of the Home Office, then as Assistant Secretary in the newly formed Department of Science and Art under Henry Cole (Macleod 1906: 36), rising to Principal Secretary by the time of his retirement in his 69th year (Nicolson 1994: 242). This department was responsible for the administration, among many other things, of a number of colleges as well as the South Kensington, Bethnal Green and Geological Museums (The National Archives, undated). By 1863 his financial situation had improved and he was once again able to take possession of Dunvegan Castle and the family started spending their holidays there (Macleod 1906: 80). Henry Cole appears to have visited Dunvegan then, given that there are two etchings of the castle in the collection of the British Museum, signed 'Dunvegan Castle/Skye. Sep/1863/H Cole' and dedicated to Mrs Macleod.

In 1876 Hanna's father, Baron Constantin von Ettingshausen, Professor of Botany at the University of Graz in Austria and an internationally recognised palaeo-botanist, 
was invited to London to prepare a fossil plant collection at the British Museum (Natural History). He subsequently made several trips to London to work on the Museum's collections (Geological Society of London 1897: 1vii). In 1876 he also lent or donated several plant specimens to the large and ambitious Special Loan Collection of Scientific Apparatus, the organisation of which Macleod was involved with in his post in the Department of Science and Art (Science and Art Department 1876: 723). It is thus likely that Norman Macleod met Baron von Ettingshausen around this time and, importantly, his daughter Hanna, whom he would marry in 1881.

In 1895 Norman Macleod died in Paris. Hanna, aged 41 and now a widow, was entitled to Dunvegan Castle's dower house, Uiginish Lodge, where she would spend the summer seasons. Then, in 1897, she married Count Vincent Baillet de Latour (1848-1913) and became Countess Latour.
While in Skye, Hanna developed an interest in the island's archaeology and excavated 'Dun an Iardhard' or Dun Fiadhairt broch (RCAHMS 1928: no. 508; MacKie 2007: 812-14; NMRS no. NG 25 SW 1), 3.5km north-west of Dunvegan, in about 1892; and later Dun Beag, near Struan, one of the best preserved brochs in Skye, in 1914-20 (RCAHMS 1928: no. 479; MacKie 2007: 82831; NMRS no. NG 33 NW 3), as well as Dun Totaig (in part), a sub-oval dun located only about 800m west of Uiginish Lodge (RCAHMS 1928: no. 519; NMRS no. NG 24 NW 6). Countess Latour was elected a Fellow of the Society of Antiquaries of Scotland in 1915. At what point she acquired the gold finger-ring under discussion, and from whom, remains unknown. However, during her excavations at Dun Beag a plain gold penannular finger-ring was found (Callander 1921: 123, fig 9, no. 3), subsequently dated to the Viking Age or Late Norse period; it is now (with her other finds) in the collection of the National Museums of Scotland (Graham-

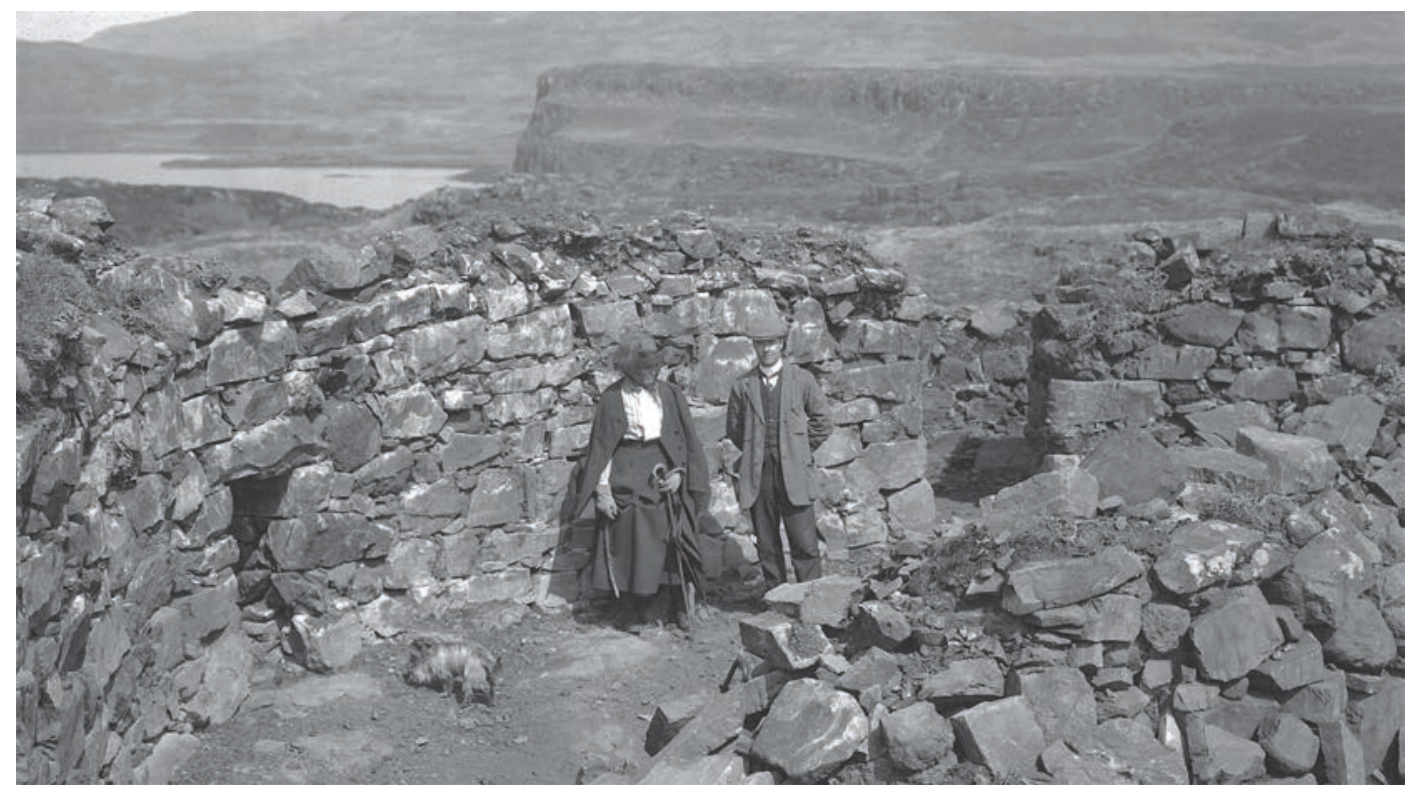

ILlus 7 View of the interior of Dun Fiadhairt, Skye, with two figures, photographed by RCAHMS in 1921 during its survey of the broch excavated by Countess Vincent Baillet de Latour, in about 1892 (when Mrs Norman Macleod). It is suggested here that the lady with the dog is Countess Latour herself, accompanied, most probably, by her manager, Donald Ferguson, to whom she presented the gold ring under discussion on his retirement in 1931. (C) Historic Environment Scotland 
Campbell 1995: 159, no. S12, pl 73, e). Although dissimilar to the Jura ring, it is conceivable that local memory or anecdotes relating to Hanna's discovery of a gold ring between 1914 and 1920 (particularly given the mysterious date of '1916' attached to it at the time of the Christie's sale), gave rise to confusion - or speculation - when she presented the Jura ring to her manager in 1931, perhaps accounting for the 'Isle of Skye' provenance that became attached to it. In the publication of Dun Fiadhairt, her manager is recorded by name as Donald Ferguson, 'in appreciation of the work done on her behalf' during the excavation (Macleod 1915: 57). It is probable that he is the male figure seen alongside the lady with a dog (presumably Countess Latour herself) in a photograph taken in June 1921 (Illus 7), in the interior of Dun Fiadhairt, during its survey by the Royal Commission on the Ancient and Historical Monuments \& Constructions of Scotland (RCAHMS 1928: 157-8, no. 508).

Another possible scenario is that the ring was sold (or given) to Countess Latour with a spurious 'Isle of Skye' provenance to make it appear more attractive to her, but, more probably, Christie's may just have assumed that it had been found in the Isle of Skye given its most recent history on being consigned for sale.

Any such confusion, speculation, deception or assumption could account for the 'Isle of Skye' provenance attached to the finger-ring on the occasion of its sale in 1979 when, as described above, it was acquired by Glasgow Museums. It was subsequently displayed in Kelvingrove Museum and in the major touring exhibition 'Vikings: The North Atlantic Saga', initiated by the National Museum of Natural History in Washington DC, in 2000 (Fitzhugh \& Ward 2000: 16-17). The ring has been on display in Kelvingrove Museum's 'Scotland's First People' gallery since 2006 .

\section{THE ‘ISLE OF JURA (1869)’ HOARD}

This four-rod ring from Jura represents 'a good example of the long-lived type of twisted rod finger-ring, closely paralleled by the three-rod ring from Whalsay, Shetland' (Graham-Campbell
1995: 159, 160, no. S14, pl 73, g), but with its lopsided appearance serving to distinguish it from all the other examples known from both Scotland (Graham-Campbell 1995: pls 50, 73) and England (Graham-Campbell 2011: pl 82).

It is unfortunate that Waddell provides no description of the second gold ring (now lost), other than that they were found 'two of them together, so late as 1869' (Waddell 1875: 305), for such a pair of finger-rings from the Viking Age/Late Norse period need not necessarily be of the same type. It is of course possible that both were manufactured from twisted rods, although the other could just as well have been simpler in form - consisting of a single rod or band. On the other hand, the lost ring might have been of the more elaborate type manufactured from plaited rods. For instance, the four gold finger-rings constituting the Viking Age gold hoard from Stenness, Orkney (Graham-Campbell 1995: 130-1, no. 27, pl 50, b) consist of one plaited (six-rod) and one twisted (three-rod), both of annular type (as that known from Jura), and a further pair in the form of plain penannular bands (as that from Broch of Struan). From the Western Isles, the single find of a gold finger-ring on Fladda-chùain, off Skye, represents a yet more elaborate version of the annular type, being an eight-rod plait (Graham-Campbell 1995: 154, no. S3, pl 73, b). This is, however, paralleled in the gold hoard most probably from North Uist (Graham-Campbell 1995: 127-9, no. 25, pl 50 , a). Two gold finger-rings of differing types form part of the coin hoard from St Blane's, Bute, deposited in the 1150s: one is annular and the other penannular, with the former being a standard three-rod twist and the latter a single plain rod (Graham-Campbell 1995: 165-6, nos $\mathrm{U} 4$ \& U5, pl 73, h-i). There is a similar difference between the two gold finger-rings in a coin hoard deposited in the south of England, $c 1068$, at Soberton, Hampshire, although in this case one is a six-rod plait (Graham-Campbell 2011: 243, no. $7, \mathrm{pl} 82$ ). The nature of the second Jura fingerring has to therefore remain an open question.

No other hoard known from Scandinavian Scotland consists exclusively of a pair of gold finger-rings, but a couple of such finds are on record from England: from Chichester, West 
Sussex, and Great Wratting, Suffolk, but these rings are of different (late) types to the extant Jura ring (Graham-Campbell 2011: 13, figs 1.141.15).

The recognition of this gold finger-ring hoard from Jura is of particular local significance because otherwise "no Viking period graves, hoards or artefacts indicative of Scandinavian settlement' have been found in the island, 'although a diver in the Sound of Jura, in 1981, recovered a splendid gold arm-ring from the seabed, near Ruadh Sgeir' (Graham-Campbell \& Batey 1998: 89). This is a fine example of a standard twisted-rod annular arm-ring (two-rod), with a ring-stamped linking plate (GrahamCampbell 1983; 1995: 164, no. S24, pl 72, c-d). In this case its seabed location is suggestive of ritual deposition in a 'watery place', as seems to have been the case with a number of other such single finds of Viking Age gold rings (GrahamCampbell \& Sheehan 2009).

\section{CONCLUSION}

Writing comprehensive life histories of single artefacts in museum collections requires the writer to have information about all stages of the artefacts' lives. This significantly limits the pool of suitable artefactual candidates as many antiquarian museum objects, the Jura ring included, frequently lack detailed documentation about their lives prior to discovery or acquisition. However, not having the full range of data available to us does not mean that taking a biographical approach to object study cannot be fruitful and rewarding.

Gosden and Marshall describe object biography as a metaphor for the way human and object histories are intertwined: 'Meaning emerges from social action and the purpose of an artefact biography is to illuminate that process' (Gosden \& Marshall 1999: 169-70). Seen in this light, the inability to consistently produce neat, linear accounts of every stage of an object's journey is not a defect of the biographical approach. Rather, this approach offers the opportunity to probe the object's associations with people for whom it had meaning and to extract meaningful narratives from these relationships; in other words, we can construct biographies that consist of 'a series of connected jumps' (Joy 2009: 544) as objects move between owners.

One example of how this might work has been given in this paper. Uncovering the lost provenance of the Jura ring opened the door on a previously unknown chapter of the ring's life. Although gaps remain in our knowledge about precisely how the ring moved from owner to owner, the addition of the story of Waddell's ownership has nonetheless enriched its biography. By recontextualising the ring within the lives of people who encountered it we are able to discern some of the different identities it acquired, beyond those which it has had in the distant past, as a personal ornament, and in the recent past, as a museum object. We learn how the ring served as archaeological evidence - a tangible vestige of Waddell's romanticised Ossianic past - and how it served a function in creating a bond between giver and receiver as a retirement present from the Countess Latour to a valued employee - a person who had assisted her in her own antiquarian endeavours - before becoming an heirloom. The ring's career as a Bronze Age earring was short lived, as it entered the collection of Glasgow Museums. As a Viking Age or Late Norse finger-ring on display at Kelvingrove Museum it no doubt continues to mean different things to different people.

\section{REFERENCES}

Callander, J G 1921 'Report on the Excavation of Dun Beag, a Broch near Struan, Skye', Proc Soc Antiq Scot 55: 110-31.

Christie's 1979 Fine Antiquities: Wednesday, 28 November 1979. Christie's auction catalogue. London.

Clerk, A 1870 The Poems of Ossian in the Original Gaelic. Edinburgh: Blackwood.

Devine, T M 1994 Clanship to Crofters' War. Manchester: Manchester University Press.

Fitzhugh, W W \& Ward, E I (eds) 2000 Vikings: the North Atlantic Saga. Washington: Smithsonian Books. 
Gaelic Society of Inverness 1878 'Dr Hately Waddell on the Authenticity of Ossian', Transactions of the Gaelic Society of Inverness 6: 63-87.

Geological Society of London 1897 'Obituary of Baron Constantin von Ettingshausen', Quarterly Journal of the Geological Society 53: lvii.

Gidal, E 2015 Ossianic Unconformities, Bardic Poetry in the Industrial Age. Virginia: The University of Virginia Press.

Gosden, C \& Marshall, Y 1999 'The cultural biography of objects', World Archaeology 31(2): 169-78. https://doi.org/10.1080/00438 243.1999.9980439.

Graham-Campbell, J 1982 ‘An unpublished gold finger-ring of Viking-age date from the Isle of Skye, and new light on the 1850 Skye hoard', Proc Soc Antiq Scot 112: 568-70.

Graham-Campbell, J 1983 'A Viking Age gold arm-ring from the Sound of Jura', Proc Soc Antiq Scot 113: 640-2.

Graham-Campbell, J 1995 The Viking-Age Gold and Silver of Scotland (AD 850-1100). Edinburgh: National Museums of Scotland.

Graham-Campbell, J 2011 The Cuerdale Hoard and Related Viking-Age Silver and Gold from Britain and Ireland in the British Museum. London: The British Museum.

Graham-Campbell, J \& Batey, C E 1998 Vikings in Scotland: An Archaeological Survey. Edinburgh: Edinburgh University Press.

Graham-Campbell, J \& Sheehan, J 2009 'Vikingage gold and silver from Irish crannogs and other watery places', Journal of Irish Archaeology 18: 77-93.

Joy, J 2009 'Reinvigorating object biography: reproducing the drama of object lives', World Archaeology 41(4): 540-56. https://doi. org/10.1080/00438240903345530.

Lawson, Rev R 1892 Places of Interest about Girvan with Some Glimpses of Carrick History. Paisley: J \& R Parlane.

Lyell, C 1871 The Student's Elements of Geology. New York: Harber \& Brothers.

MacArthur, J 1862 The Antiquities of Arran. Glasgow: Thomas Murray \& Son.
MacGown, J 1883 'Ancient Sepulture in Cumbrae', Transactions of the Glasgow Archaeological Society 2: 114-20.

MacKie, E W 2007 The Roundhouses, Brochs and Wheelhouses of Atlantic Scotland c. 700 $B C-A D$ 500: architecture and material culture, the Northern and Southern Mainland and the Western Islands, 2 vols. Oxford: British Archaeological Reports, British Series, 444.

Maclean, H 1876 'The Ossianic Controversy', The Coleraine Chronicle 15 July 1876: 6.

MacLeod, F T 1915 'Notes on Dun an Iardhard, a Broch near Dunvegan excavated by Countess Vincent Baillet de Latour, Uiginish Lodge, Skye', Proc Soc Antiq Scot 49: 57-70.

Macleod, R C 1906 The Macleods: a short sketch of their clan, history, folk-lore, tales, and biographical notices of some eminent clansmen. Edinburgh: Clan Macleod Society.

Macnair, P \& Mort, F (eds) 1908 History of the Geological Society of Glasgow 18581908. Glasgow: The Geological Society of Glasgow.

Meek, D 2004 'The Sublime Gael: The Impact of Macpherson's Ossian on Literary Creativity and Cultural Perception in Gaelic Scotland', in Gaskill, $\mathrm{H}$ (ed.) The Reception of Ossian in Europe, 40-66. London: Bloomsbury Publishing.

Mowat, R J C 1996 The Logboats of Scotland. Oxford: Oxbow Books.

National Archives and Records of the Science and Art Department and predecessors: Administrative/biographical background. http://discovery.nationalarchives.gov.uk/ details/r/C810. Accessed 23 September 2016.

Nicolson, A 1994 (1930) History of Skye, 2nd edn, Maclean, A (ed.). Waternish: The Islands Book Trust.

Paton, J (ed.) 1890 Scottish National Memorials. Glasgow: J MacLehose.

RCAHMS 1928 The Royal Commission on Ancient and Historical Monuments \& Constructions of Scotland. Ninth Report with Inventory of Monuments and Constructions in the Outer Hebrides, Skye and the Small Isles. Edinburgh: RCAHMS. 
Science and Art Department of the Committee of Council on Education 1876 Catalogue of the Special Loan Collection of Scientific Apparatus at the South Kensington Museum, 2 vols. London.

Waddell, P H 1867 Life and Works of Robert Burns, 2 vols. Glasgow: David Wilson.

Waddell, P H 1868 'African Travel Three Hundred Years Ago', Good Words 1 September 1868: 538-47.
Waddell, P H 1875 Ossian and the Clyde, Fingal in Ireland, Oscar in Iceland or Ossian Historical and Authentic. Glasgow: J MacLehose.

Waddell, P H 1892 Selections from the Published Writings of the Rev. Dr Peter Hately Waddell. Edinburgh: Privately printed.

Wünsch, E A 1865 'Discovery of Erect Stems of Fossil Trees in Trappean Ash in Arran', Geological Magazine 2(16): 474-5. 